\title{
マウスの弱毒肺炎球菌感染について
}

\section{2. 威染子免疫機序子の関係について}

\author{
沢井・芳男
}

東京大学傳染病研究所

[受付：.10月 18 日, 1952 年]

私は前の報告 1)に打いて, 毒力の強い肺炎球菌の 1 型 菌を，同型の免疫ウサギ血清をふくむブイオンに継代し， てえた弱毒変異株が、ウスに対して毒力が低下したばか りでなく，原菌株とは異つた病原性を獲得するようにな つたことをのべた。すなわち強毒な原菌株が菌の特異的 な苏膜のために体內で食菌作用をま奴れて方的に增 殖していくのに反して，弱毒变異株は局所に答した白 血球に直接障害作用を及ぼして，体細胞による食菌作用 をさまたげる結果, 自由に体內で增殖して逐には敗血症 へ導いていくのがその特徴であることをのべた。

このように原菌株とは異つた病原性を獲得した弱毒変 異株の㶪度機序を检討することはさらに興味が梁いと考 えられるのでこつに実驗の大要を報告する。

\section{実駩方法}

菌株は前の実驗と同樣に肺炎球菌の 1 型菌と弱毒変異 菌 1 R/44 株を用いた。マウスに対する免疫原としては, S 形菌を血液ブイョンに 20 時間培養し， 3500 r.p.m. 15 分遠心してその上清をすて, 沈澱を生理食塩水に浮游し て原量とし，1\%のわり合にホルマリンを加えて室溫に 一夜放置したのちに再び遠心してその沈澱を生理食塩水 に $1 / 2$ 量に濃維して浮游し, $75^{\circ} \mathrm{C} 15$ 分㴘浴したものを $0.5 \mathrm{ml}$ ずつマウスの大腿の皮下に接種した。注射間隔 は 1 日打きに 3 回連続して注射し，5 日休む方法を 2 回 あるいは 3 回くりかえして行つた。

R型菌による㒵疫は, $1 \mathrm{R} / 44$ 株の血液ブイヨン培養の $0.5 \mathrm{ml}$ をマゥスに注射し, S 形菌のばあいと同じ方法で 2 回あるいは 3 回をくりかえした。

これらの不度動物に対してそれぞれ S 形菌执よ゙ $\mathrm{R}$ 形 菌のブイヨン培養を $0.5 \mathrm{ml}$ ずつ腹腔內に注射し, その 反㷳をとくに食菌作用を中心にして観察した。すなわち 注射後 1，3，5，7時間および生存していたものは 24 時 間後にガラスの毛細管で腹腔液をとりのせガラスに塗抹 標本を作り，3ないし 7 時間の腹腔液について白血球数
の計算を行つた。洛抹標本は細胞外の菌の增減の有無, 多核白血球と單核白血球との比率，および食菌数の計算 を行つた。

\section{実䣖成統}

1）免疫処置マウスに対するR形菌の攻擊

$\mathrm{R}$ 形菌およびS 形菌で㣻疫したマウス 3 匹ずつを 1 群 として, R 形菌の血液ブイヨン 20 時間培養を 3500 r.p. m. 15 分遠心してその沈搌を生理食塩水に $1 / 10$ 亿㴗縮し て浮游し（菌数は $2.4 \times 10^{10} / \mathrm{ml}$ ) その $0.5 \mathrm{ml}$ ずつをそ れぞれのマウスの腹腔に注射した。この濃縮した菌液を

\section{第 1 表 $\mathbf{R}$ 形菌および $\mathbf{S}$ 形菌て免份された マウスに対する $\mathbf{R}$ 形菌による感染}

\begin{tabular}{|c|c|c|c|}
\hline 接 種 量 & R 形菌免疫群 & S 形群免疫群 & 作無處置對炤群 \\
\hline $1.2 \times 10^{10}$ & $3 / 3$ & $3 / 3$ & $3 / 3$ \\
\hline $0.6 \times 10^{10}$ & $0 / 3$ & $3 / 3$ & $3 / 3$ \\
\hline $3.0 \times 10^{9}$ & $0 / 3$ & $2 / 3$ & $2 / 3$ \\
\hline $1.5 \times 10^{9}$ & $0 / 3$ & $0 / 3$ & $0 / 3$ \\
\hline
\end{tabular}

註 表中の分數の分子は死亡數，分母は 使用したママッス數

もとにして $1: 2,1: 4,1: 8$ に稀採し，さらにその 0.5 $\mathrm{ml}$ ずつを別の免度群に接種し，対照として正常の無処 置マウスおよびS形菌で免疫したマウンに対しても同樣 の接種を行つた。これらの実驗成樍は第1表に示された ようにR形菌の炛疫群マウスのなかで， $1: 2 ＼mathrm{~ お よ ひ ゙ ~} 1$. : 5 に稀釈した菌液の攻擊をらけた群が感染を防禦して 生存した。そのほかの感染をおこしたマウスは 6 時間か ら20時間のあいだに死んだ。

SAWAI, Yoshio: Studies on the Infection in Mice caused by $\mathrm{R}$ Type of Pneumococcus. II. On the Relationship between Infection and Immunity. The Institute for Infectious Diseases, The University of Tokyo. - Jap. J. of Bact., 8(2): 2072091953. 
腹腔液の塗抹標本は, 10 倍に濃縮した菌の接種群では $\mathrm{R}$ 形菌免疫を行つたものでは， S 形菌あるいは無処置の 対照にくらべると，菌の增殖がおくれ，局所の出白形 球の溶解が多少おくれる傾向が文られるだけであつた。

すなわち前者では白血球の減少は感染後 7 時間で著明 にみられたのに反して後者では3時間ですでに著明であ つた。つぎに感染を防䍌した動物群すなおち $1: 2$ に稀 勫した菌液を接種した $\mathrm{R}$ 形菌免疫群では腹腔にいれられ た菌は 3 時間あるいは少くとも 5 時間以內に腹腔から消 失し, 白血球の溶解現像はみられずに白血球の增加が順 調におこり食作用が有効にはたらいて, 細胞外の菌が消 失したのちも， 7 時間までの標本には多数の菌が 細胞內 にとりこまれているのがみられた。るちろん 24 時間後 は細胞內の菌孔陰性となつた。出細胞の種類の 3 時間 ないし 5 時間から單核の 食細胞から多核白血球にかわ り，食菌も主として後者の細胞によつて行われた。また さらに $1: 5$ に稀釈した菌液を接種した $\mathrm{R}$ 形菌免疫群に ついても，ほよ゙同樣の所見がえられた。これに反してS 形菌免度群及び無処置の対照群では，3時間ないし 5 時 間で白血球の崩解と菌の䝬殖が著明におこり，ごく少数 の残された白血球は多数の菌をとりこんでいたが，いず れも障害をうけ細胞の境界が不明僚であつたためい細胞 內の菌数を正確に計算することが困難であつた。

この樣にしてR形菌による免疫マウスは攻擊菌による 食紐胞の溶解をふせぐことによつて感染を防禦すること ができたが， S 形菌の免疫群と無処置の対照群は共に感 染を防笄することができなかつた。

2）免疫処置マウスに対するS形菌の攻擊

R形菌およびS 形菌で免疫したマウスにS 形菌の攻擊 を行い，その $\mathrm{LD}_{50}$ を第 2 表に示した。すなわち 3 匹ず つのマウスを一群として, S 形菌の血液ブイョン培養を 10-1 から 10-9 まて階段稀䣋を行つて，その $0.5 \mathrm{ml}$

\section{第 2 表 $\mathbf{R}$ 形菌および $\mathbf{S}$ 形菌て免疫された} マウスの S 形菌感染による $\mathbf{L D}_{50}$ の差異

\begin{tabular}{ccc|c}
\hline 免 & 疫 & 原 & $\mathrm{S}$ 形菌に對する $\mathrm{LD}_{50}$ \\
\hline $\mathrm{R}$ & 形 & 菌 & $10^{-5.5}$ \\
$\mathrm{~S}$ & 形 & 菌 & $10^{-1.5}$ \\
無處置對照 & $10^{-8.8}$ \\
\hline
\end{tabular}

つをマウズの腹腔に注射すると, 前の実驗で R 形菌の攻 擊に対して全く無抵抗であつた S 形菌免疫群のマウス は，S形菌の攻擊に対して強い抵抗性をしめした。すな わち $\mathrm{LD}_{50}$ が無処置の対照が 10-8.8 であるのに, $\mathrm{S}$ 形菌
免疫マウスでは $10^{-1.5}$ であつた。

ところが型特異性を失つた $\mathrm{R}$ 形菌で免疫した群のマウ スにも，S 形菌免疫群にくらべれば劣つてはいるが，そ の $\mathrm{LD}_{50}$ は 10-5.5 を示し，な执かなりの程度の感染防 禦能のあることを示している。

このばあいに $10^{-1}$ に稀勫した S 形菌を $0.5 \mathrm{ml}$ ずつ 注射した群では，3匹のうち2匹が生存し， 1 匹が 20 時間以內で死亡したが，これらの動物の腹腔内の食菌の 狀態をたどつてみると，生存例では菌は注射後 2 時間な いし 3 時間で局所から消失したが，死亡例では無処置の 対照にくらへて菌の璔殖がや〉おくれる傾向を示した が，注射後 5 時間ぐらいから增殖が著しくなり，やがて 敗血症に移行した。格出性の多核白血球, 及びそれらと 單核白血球との比率は, 正常動物に対するS 形菌の感染 の対照とほとんど変りがなかつた。またこれらの細胞に よる食作用は接種菌量が少く菌の消失が早いためめ, 注 射後 1 時間ないし 2 時間後の桑抹標本にわずかにみられ たにすぎなかつた。R形菌冤疫群に対して10-1のS 形菌 を接種して死亡した動物の腹腔內の所見は無処置の対照 群と区別できなかつた。

以上の実驗から， S 形菌で免度した動物は $\mathrm{S}$ 形菌の攻 㩓に対しては強い防禦能力をもちながら， R 形菌の感染 には全く無能である,とい5事実からして両者の菌による 免疫機序が異つていることが推測される。すなわちS形 菌に対する免疫機序は從来からみとめられているょうに anti-capsular であるのに反して，R形菌に対する挽疫 機序は anti-leucolytic であるといえる。何故ならばR形 菌の免度によつて, 刘照の無処置の動物におこつてくる 这出白血球の溶解がくいとめられて, 正常の食菌能力が 保持されたからである。

たら゙ひとつの問題は，S 形菌による免疫では何故この anti-leucolytic の能力が附與されないのかということで あるが，現在のところなお不明である。あるいは免疫原 の製法に問題があるのかも知れない。

つぎに R形菌で免疫したマウスは $\mathrm{S}$ 形菌の感染もある 程度ふせいでいることからして, もし R形菌が全く型特 異的な多糖質に対する抗体を作る能力をもたないとすれ ば，S形菌に対する免疫機序は單に anti-capsular の及 であるかどうかが疑間となつてくる。これ等の事実と関 連して Tillett 2)（1927，1928 年）が弱毒変異菌の否疫に よつて型特異的な肺炎球菌の感染を防ぐことができるこ とを示している。 
日本細菌學雜誌，8(2)，1953

\section{総括}

肺炎球菌の 1 型菌から変異した $\mathrm{R}$ 形の 弱毒菌（IR/44 株）に対するマウスの免疫機序は，原株のそれとは巽つ て, R形菌による局所の出細胞の溶解を防いで, 食作 用を維持して感染を防禦するところの anti-leucolytic な ものである。
(本研究の大要は昭和 27 年 6 月 20 日第 6 回日本細菌学 会関東支部総会で演述された。）

文献

1）沢井芳男, 田中光：日本細菌学雜誌.7(5), 515$518,1952$.

2) Tillett, W. S. : J. Exp. Med., 46, 343, 1927.

3) Tillett, W. S. : J. Exp. Med., 48, 791, 1928. 